\title{
Relationship between Migration Characteristics, Attitude to Money, Financial Anxious and Intentions to Work Unlawful in Foreign Country: Case in Vietnam
}

\author{
TUNG PHUONG HUU ${ }^{1}$, HUONG NGUYEN THI MAI ${ }^{2 *}$ \\ ${ }^{1}$ Faculty of Human Resource Management, Ha Noi University of Home Affairs, \\ 371 Nguyen Hoang Ton Street, Bac Tu Liem, Hanoi, VIETNAM \\ ${ }^{2}$ University of Economics and Business, Vietnam National University, \\ 144 Xuan Thuy Street, Cau Giay, Hanoi, VIETNAM \\ Corresponding author: Nguyen Thi Mai Huong;
}

\begin{abstract}
Vietnamese people involved in illegal work abroad have received worldwide attention in recent times. Studies that explore the causes of this fact are mainly qualitative. This study applies a quantitative research method to clarify the relationship between emigration personality, Attitude towards money, financial anxiety, and intention to engage in illegal labour to fill that overseas gap law of Vietnamese people. This study was conducted through a cross-sectional survey using a targeted sampling technique of 400 study participants. The SEM model is used to test the hypotheses posed, and the research results through the model show that: (i) Migration personality has a positive and significant impact on attitudes about money; (ii) Financial anxiety and intention to engage in illegal work abroad; (iii) Attitudes towards money positively and significantly affect intention to engage in illegal work abroad; (iv) Financial anxiety has a positive and significant impact on intention to engage in illegal work in the country; (v) There exists a positive and significant relationship between emigration personality and attitudes towards money; Attitude towards money with financial anxiety; Financial anxiety about the intention to engage in illegal work abroad. The conclusions of this study provide valuable data for government policymakers.
\end{abstract}

Keywords: Migration personality; Attitude towards money; Financial anxiety; Intent; Labour abroad; Unlawful; Vietnam.

Received: June 8, 2021. Revised: November 10, 2021. Accepted: November 28, 2021. Published: December 28, 2021.

\section{Introduction}

According to ILO research, Vietnam recently recorded an increase in people going abroad to work. In 2019 alone, more than 142,000 migrant workers (of which about 50,000 are women) worked under contracts [66]. According to the Government of Vietnam estimates, migrant workers send home \$2.5-3 billion per year. Sending workers to work abroad is a policy of the Party and the State in the trend of integration and opening up, in line with the current international migration trend. This activity is increasingly expanding to many countries and territories, creating more job opportunities with higher incomes for Vietnamese workers, besides improving the living standards of a part of the population and reducing hunger poverty, social stability and building a skilled workforce and industrial style [26]. Currently, about 6 million Vietnamese people are living and working in all continents of the world. The number of Vietnamese going abroad is increasing day by day for different purposes, posing new requirements and tasks for the protection of Vietnamese migrants abroad [53]. There are four forms of sending Vietnamese workers to work abroad legally:

- Service enterprises or non-business organizations are allowed to send Vietnamese workers to work abroad.

- Enterprises winning bids, accepting contracts, investing abroad.

- Enterprises send workers to work as trainees to improve their skills.

- Going to work under an individual contract.

The majority of workers go to work abroad through service enterprises and non-business units that have functions and are licensed to send Vietnamese workers to work abroad [26].

However, due to various reasons, many Vietnamese workers have broken their contracts to become illegal workers. For example, they want to have a higher income, longer working time. The fraud in 
labour export in Vietnam has caused some labourers to break their contracts and reside illegally. Many brokerage organizations have scammed people who do not know; when they go abroad, they realize that they have been cheated, so they evade the police and accept illegal residence to find another job to earn money return invested capital [91]. According to the United Nations Economic and Social Council, human trafficking networks smuggle about 18,000 Vietnamese to Europe every year. Studies show that Vietnamese people working illegally in Europe often come from rural and impoverished areas of the country, where they have few economic opportunities [55]. Workers in Eastern Europe are often promised princely wages of up to $£ 3,000$ ( $\$ 3,800$ a month), about three times the annual income in Vietnam's most impoverished provinces [1].

In 2019, according to Vietnam's Ministry of Foreign Affairs, Vietnam's Ministry of Public Security, and Vietnam's Border Guard, they identified 211 cases of human trafficking (the corresponding figure in 2017 was 350 cases and in 2016 was 234 cases). More than 276 people are accused of human trafficking (more than 500 people in 2017 and 308 in 2016, respectively) [94]. The People's Procuratorate at all levels reported that 194 defendants had been prosecuted for human trafficking (245 defendants in 2017, 295 defendants in 2016, 442 defendants in 2015 and 472 defendants in 2014), and the court system sentenced 213 defendants (the corresponding figure in 2017 was 244 defendants, in 2016 it was 275 defendants); sentence from under three years to 20 years in prison; however, some defendants who were sentenced to prison were given suspended sentences. Government agencies continue to report inconsistent, overlapping, or incomplete data on anti-trafficking law enforcement and victim identification, and authorities often fail to separate cases-human trafficking with migrant smuggling cases [94].

Article 17 of the 2013 Constitution of the Socialist Republic of Vietnam states that: "Vietnamese citizens abroad are protected by the State". Implementing the above provisions of the Constitution, the State of Vietnam has promulgated a system of legal documents regulating social relations related to the migration of Vietnamese citizens abroad. There are about 53 legal and sublaw documents related to migration [53]. In general, the current law of Vietnam has relatively specific provisions to protect the rights to health, life, honour, dignity and other legitimate interests of citizens while living work, study, marry and adopt children abroad. Vietnam actively cooperates in human trafficking prevention and combat with countries with shared borders and countries with many Vietnamese people living through the signing of bilateral cooperation agreements with neighbouring countries, such as China, Laos, Thailand, Malaysia [53]. As assessed by studies, the Vietnamese government has not yet fully met the minimum standards for the elimination of human trafficking but is making significant efforts to do so [94]. These efforts include disseminating guidelines for the implementation of Articles 150 and 151 of the Penal Code, and conducting largescale awareness campaigns in communities at high risk of trafficking.

Moreover, it organizes government-supported training courses for consular officers, police and other relevant agencies to combat human trafficking [94]. The delay hampered law enforcement efforts in issuing official documents guiding Articles 150 and 151 of the Vietnamese Penal Code. The absence of an interagency coordination mechanism and the lack of understanding by provincial officials about antitrafficking laws and victim protection issues hinder efforts to combat human trafficking [94].

This fact requires quantitative studies to explore the factors affecting illegal immigration and illegal labour of overseas Vietnamese. The objective of this study was to explore the Vietnamese people's intention to join illegal work abroad concerning their emigration personality, attitudes towards money, and financial anxiety.

\section{Literature Reviews}

\subsection{Migration Personality}

The decision to migrate is a complex process also influenced by non-economic factors such as cultural differences [6] and an individual's perception of migration's potential costs and benefits. Published studies have found that perceptions of migration are shaped by factors such as preferences [5], [22], [36]; psychological predispositions [27], the attractiveness of regions, prosperous and developed countries [8], [56], [65]. In addition, studies have found that culture is one of the non-economic aspects affecting the attractiveness of alternative destinations for potential migrants [5], [6], [96], However, there is still a lack of understanding of different personality differences in individual intentions to migrate. Personality traits can be introduced into individual decision mechanisms through constraints, 
preferences, and expectations [3], [9], Different individuals in their personality traits can lead to different constraints [9]. Preferences and expectations are two factors through which personality traits can influence migration decisions. Personality traits influence expectations based on how individuals perceive and process information in different ways [3]. For example, people who are more open to new experiences can gather more information [3]. Depending on their personalities and how they construct their information sets, individuals may also predict, inflate, or deflate the benefits expected to be gained in alternative locations, influencing their decisions.

Few studies have found a relationship between personality and migration intention and behaviour [88]. There is a negative association between conscientiousness and intention to migrate [88]. In contrast, there is a positive association between conscientiousness and intention to migrate [44]. There is no positive association between migration intention and affable personality [64]. In contrast, there is a positive association between migration intention and pleasant personality [44]. Notable are the following studies:

Extraversion migrants have increased mobility intentions and are more likely to seek out new experiences in their destination [80], [81]. Open personality intends to migrate [62], [44]. Migrants with a thirst for adventure have the persistence needed to undertake migration [81], [33] successfully. There is a relationship between the calculation of migration decisions and economic prospects. The purpose of migration is to open up the possibility of making much money [4], [14]. Open-mindedness is positively associated with high migration propensity (Ayhan et al., 2017). People with migratory and open personalities have adaptive skills and substantially impact migration [14]. There is a positive association between migratory personality, openness and intention to migrate [16], [17], [44], [45]. Highly social individuals (i.e., extroverts) are more likely to travel longer distances and prefer urban areas, while highly emotional individuals tend to travel longer distances. shorter way [45].

In summary, the extraversion personality is characterized by being talkative, sociable, enterprising, adventurous, and optimistic [34]. People with this personality trait are more likely to be willing to move into new social groups [71]. The open personality is characterized by creativity, curiosity and connection [34]. This personality is highly likely to migrate because it wants to experience novelty about location, social networks and culture [17], [44], [64]. Therefore, we hope to find a positive association between emigration personality and attitudes towards money, financial anxiety, and intention to engage in illegal work abroad.

\subsection{Attitude Towards Money}

Attitudes towards money relate to individual behavioural intentions. The theory of monetary intelligence (MI) asserts that individuals apply their attitudes to frame significant concerns in context and strategically choose confident choices to achieve financial goals and ultimate happiness [86]. Attitude towards infringes upon an individual's actions and his way of thinking [74]. Individuals seek to increase wealth and maximize the utility generated from money [28]. However, since individuals also have other important goals (getting power, enjoying life) besides accumulating wealth, these goals entirely influence an individual's attitude towards their decisions and behaviour. Thus, the symbolic meaning of money becomes a necessary aspect and may even exceed its economic value [57]. Individuals with solid beliefs will use the money to impress others and gain social recognition [100]. Individuals use the money to plan and prepare for the future [100].

Studies show that different aspects of an individual's attitude towards money can be influenced by age, sex, education, income and ethnicity [29], [35]. People who emphasize money as a sign of their achievement may have low satisfaction with their current job, promotion, supervision, co-workers, and overall life satisfaction [32].

Money lovers see money as helping them improve their self-esteem [82], [101], [102], helping themselves be recognized (respected) by others. In the context of materialism, money is power [54]. Salary-minded people wanting more are widely recognized as an essential motivator for work. People who value money have a stronger desire than others for wealth and can therefore be expected to work more or strive for higher-paying jobs [72]. People who focus on money work hard for high income, and thus they are satisfied with their job, salary and promotion [82]. People appreciate what they own and create a celebrity possessive effect [49].

In poverty and limited prospects, many individuals are willing to take risks to seize opportunities abroad to earn more money. The prevailing notions of charm and opportunity in wealthy countries of stable employment, better living conditions, and access to hard currency seem to offer a way out of 
endless difficulty [30]. It sets the stage for human trafficking and illegal immigration, as people without legal immigration conditions depend on illegal intermediaries for passport purchases and transportation [30]. It involves human trafficking, forced labour, and slavery [30].

Money-focused people believe that using the money for social comparison, power-seeking, ostentatiousness and overcoming self-doubt leads to low subjective well-being [24], [77]. Does emigration affect attitudes about money? We use MI to test the impact of money attitudes on intention to become an illegal worker abroad based on theoretical guidance [25], [32], [60], [70], [83], [85], [84], [98], [78].

\subsection{Financial Anxiety}

In poverty and limited prospects, many individuals are willing to take risks to seize opportunities abroad to earn more money. The prevailing notions about attractiveness and opportunity in rich countries about stable jobs, better living conditions and access to money seem to offer a way out of trouble [30].

Ability to handle financial emergencies, meet basic needs, debt level, savings and funds for future financial needs and life goals [41]. Financial anxiety is, directly and indirectly, related to aspects of mental health and is a source of stress in life. Financial stress is mentioned more often by young and middle-aged people [99]. Financial anxiety is associated with adverse psychological effects such as higher stress levels [31], [47], [52]. Financial anxiety can adversely affect an individual's job [13]. Financial satisfaction is an integral component of overall life satisfaction and happiness [67]. Satisfaction with one's financial status needs to consider both the material and immaterial aspects of one's entire financial situation [47]. Many Vietnamese people want to settle abroad because they are not satisfied with their current life; the focus is on financial issues. There are many reasons for their dissatisfaction, such as poverty. High urban unemployment is the primary reason workers feel the need to migrate for work and, therefore, are at risk of being used and exploited by traffickers [30]. Many people want to study abroad so they can pursue immigration opportunities. The interviewees explained that their intentions stem from the fact that the quality of life in Vietnam is not good enough. Some interviewees implied that they were dissatisfied with political issues and social injustices in Vietnam, so immigration through the pursuit of international education is a possible option [90].
In most developing countries, poor economic, political and social infrastructure contributes to poverty, conflict, and bad governance, forcing some people to leave and seek opportunities elsewhere [30]. These poor people traverse irregular channels and dangerous, dangerous and circuitous routes, becoming victims of human trafficking [30]. Income poverty, unemployment, hunger, disease and illiteracy are widespread, leading to illegal overseas migration and human trafficking [10], [92]. There are long-term shortages of jobs, education, vocational training and economic opportunities. As a result, unemployed youth and school dropouts are less able to work and thus become easy targets for traffickers [10], [92]. More vulnerable are those who migrate from rural areas, where opportunities are even rarer, to urban areas searching for work and other opportunities. At their point of vulnerability, young people, both men and women, are seduced by ruthless traffickers for reasons such as the promise of marriage, employment, educational opportunities, or a life to live better [10], [92].

To date, no studies have investigated the link between financial satisfaction and the intention to engage in illegal work abroad. Whether there is a link between engaging in illegal work abroad to satisfy the financial need, the article will examine the relationship between financial anxiety and intention to join illegal work abroad.

Based on the above studies, the article sets forth the following research hypotheses:

H1. Migration personality has a positive and significant impact on attitudes about money.

H2. Migration personality has a positive and significant impact on intention to engage in illegal work abroad.

H3. Migration has a positive and significant effect on financial anxiety.

H4. Attitudes towards money have a positive and significant effect on the intention to engage in illegal work abroad.

H5. Financial anxiety has a positive and significant effect on the intention to engage in illegal work abroad.

H6. There exists a positive and significant association between emigration personality, attitude towards money, financial anxiety and intention to engage in illegal work abroad. 


\section{Materials and Methods}

\subsection{Variables and Measures}

Examine attitudes towards money, and the study uses the Money Ethic Scale developed by Tang, Thomas Li-Ping in 1998 [87]. Money Ethic Scale includes 27 items in 6 factors, including Achievement/Obsession (Achievement); Good; Power; Expression; Evil; Management of Money. Each item is measured on a 5-point Likert scale (Disagree strongly $=1$; Disagree a little $=2$; Neither agree nor disagree $=3$; Agree a little $=4$; Agree Strongly $=5$ ). Scale is translated into Vietnamese by the linguist. It has been adjusted in terms of grammar to suit Vietnamese people.

Test migratory personality, the Big-Five trait taxonomy scale [34] was used. This scale includes 44 items in 5 factors. Each item is measured on a 5point Likert scale (Disagree strongly $=1$; Disagree a little $=2$; Neither agree nor disagree $=3$; Agree a little $=4$; Agree Strongly $=5$ ). This scale is also translated into Vietnamese by language experts and adjusted to suit Vietnamese people.

In order to test the intention to join illegal labour abroad, we built a scale consisting of 6 items (Appendix, Chart 12). Each item is measured on a 5-point Likert scale (Disagree strongly $=1$; Disagree a little $=2$; Neither agree nor disagree $=3$; Agree a little $=4$; Agree Strongly $=5$ ). A selfassessment questionnaire was developed after consulting experts in the fields of immigration, labour, and law. After completing the questionnaire, we conducted a survey and analyzed the trial with adjustment. Items with a Cronbach alpha of less than 0.5 were included in the questionnaire. The questionnaire consists of three parts:

A survey of population information including age, education, employment status;

Attitude section towards money;

Immigrant personality and intention to engage in illegal work abroad.

The personality test with the symbol $\mathrm{R}$ is people questions-details of items in chart 1.

\subsection{Data Collection}

The design used for the study was a cross-sectional survey design that aimed to measure the independent variables considered as factors of emigration personality, attitudes towards money, financial anxiety, and Vietnamese people's intention to join illegal labour. The study participants included farmers, workers. The study was conducted in the central provinces of Vietnam in November 2019. Data collection through a questionnaire survey. The number of votes is $(n=)$ 400. Respondents mark the correct options with a pencil. Collected data were analyzed using SPSS 2.0 and SPSS AMOS 2.0 software. One hundred faulty questionnaires should be discarded, and only 300 remained included in the analysis. Demographic information, including gender, education, employment status and personality, is described in Appendix. As for the data of the personality section, we swapped the items in reverse, detailed in chart 1.

Table 1. Frequency analysis

\begin{tabular}{|l|l|c|c|c|c|}
\hline Factors & Items & Male & Female & Total & Percent \\
\hline \multirow{4}{*}{ Education } & High school or less & 81 & 111 & 192 & 64.0 \\
\cline { 2 - 6 } & Bachelor or technical degree & 25 & 34 & 59 & 19.7 \\
\cline { 2 - 6 } & Honours or higher & 19 & 30 & 49 & 16.3 \\
\hline \multirow{4}{*}{ Age } & From 20 to 30 years old & 19 & 30 & 49 & 16.3 \\
\cline { 2 - 6 } & From 31 to 40 years old & 81 & 111 & 192 & 64.0 \\
\cline { 2 - 6 } & Over 40 years old & 25 & 34 & 59 & 19.7 \\
\hline \multirow{3}{*}{$\begin{array}{l}\text { Employment } \\
\text { status }\end{array}$} & Unemployed & 19 & 30 & 49 & 16.3 \\
\cline { 2 - 6 } & Employed & 94 & 125 & 219 & 73.0 \\
\cline { 2 - 6 } & Student & 12 & 30 & 42 & 14.0 \\
\hline
\end{tabular}




\section{Results}

\subsection{Reliability Analysis}

Cronbach's Alpha coefficient is a coefficient that allows assessing if it is appropriate to include certain observed variables that belong to a research variable (latent variables, factors). The items in table 3 have Cronbach's Alpha coefficient greater than 0.8. All items have Cronbach Alpha coefficient $>$ eight and corrected item-total correlation $>0.3$, so they are accepted as reliable [40], [61], [20].

Table 2. Reliability Analysis

\begin{tabular}{|l|c|c|c|}
\hline Factors & $\begin{array}{l}\text { Average Variance } \\
\text { Extracted }\end{array}$ & Cronbach's alpha & Composite Reliability \\
\hline Openness & 0.473 & 0.899 & 0.899 \\
\hline Extraversion & 0.562 & 0.884 & 0.885 \\
\hline Achievement & 0.602 & 0.900 & 0.901 \\
\hline Power & 0.748 & 0.937 & 0.937 \\
\hline Good & 0.580 & 0.873 & 0.873 \\
\hline Expression & 0.773 & 0.931 & 0.932 \\
\hline Worry & 0.727 & 0.930 & 0.942 \\
\hline Intent & 0.470 & 0.840 & 0.841 \\
\hline
\end{tabular}

Reasonable composite confidence for a construct was defined with five to eight entries to meet the minimum threshold of 0.80 [68], [12]. Items in chart 3 have total confidence $>0.8$. Thus, all items meet the requirements to perform the analysis of the next steps. The average Variance Extracted acceptance threshold of entries is more significant than 0.50 [39]. Chart 2 shows items with Average Variance Extracted greater than 0.50, including extraversion, achievement, power, sound, expression and worry. Therefore, these items are accepted for analysis to proceed with the following steps. However, openness and intent entries with an Average Variance Extracted index of approximately 0.5 but composite reliability greater than 0.8 are still acceptable. Because if the average is less than 0.5 but composite reliability is higher than 0.6 , the convergent validity of the construct is still adequate [39].

\subsection{Factor Analysis}

The condition for exploratory factor analysis is to satisfy the following requirements: Factor loading $>0.5$. $0.5 \leq \mathrm{KMO} \leq 1$ : KMO coefficient (KaiserMeyer-Olkin) is an index used to consider the appropriateness of factor analysis [18], [50]. Chart 5 shows that the Bartlett test has statistical significance (Sig. $=0.00$ ), coefficient $\mathrm{KMO}=0.946$ is valid for factor analysis. Chart 3 shows that Total Variance Explained $=66.748 \%$ is valid [39]. Initial Eigenvalues of 6 factors $=1.636$ (greater than 1.40) are valid [75].

Table 3. Total Variance Explained

\begin{tabular}{|c|c|c|c|c|c|c|c|c|c|}
\hline \multirow{2}{*}{ Com } & \multicolumn{3}{|c|}{ Initial Eigenvalues } & \multicolumn{3}{c|}{$\begin{array}{c}\text { Extraction Sums of } \\
\text { Squared Loadings }\end{array}$} & \multicolumn{3}{c|}{$\begin{array}{c}\text { Rotation Sums of Squared } \\
\text { Loadings }\end{array}$} \\
\cline { 2 - 10 } & Total & $\begin{array}{c}\text { \% of } \\
\text { Varian } \\
\text { ce }\end{array}$ & $\begin{array}{c}\text { Cumulati } \\
\text { ve \% }\end{array}$ & Total & $\begin{array}{c}\text { \% of } \\
\text { Varianc } \\
\text { e }\end{array}$ & $\begin{array}{c}\text { Cumulati } \\
\text { ve \% }\end{array}$ & Total & $\begin{array}{c}\text { \% of } \\
\text { Varian } \\
\text { ce }\end{array}$ & $\begin{array}{c}\text { Cumulative } \\
\text { \% }\end{array}$ \\
\hline 1 & 16.027 & 34.100 & 34.100 & $\begin{array}{c}16.02 \\
7\end{array}$ & 34.100 & 34.100 & 5.656 & 12.035 & 12.035 \\
\hline 2 & 3.107 & 6.611 & 40.711 & 3.107 & 6.611 & 40.711 & 4.151 & 8.831 & 20.866 \\
\hline 3 & 2.426 & 5.162 & 45.873 & 2.426 & 5.162 & 45.873 & 4.052 & 8.622 & 29.487 \\
\hline 4 & 2.228 & 4.741 & 50.614 & 2.228 & 4.741 & 50.614 & 3.865 & 8.224 & 37.712 \\
\hline 5 & 2.155 & 4.584 & 55.198 & 2.155 & 4.584 & 55.198 & 3.827 & 8.143 & 45.854 \\
\hline 6 & 2.012 & 4.282 & 59.479 & 2.012 & 4.282 & 59.479 & 3.485 & 7.415 & 53.269 \\
\hline 7 & 1.781 & 3.789 & 63.268 & 1.781 & 3.789 & 63.268 & 3.370 & 7.171 & 60.440 \\
\hline 8 & 1.636 & 3.480 & 66.748 & 1.636 & 3.480 & 66.748 & 2.965 & 6.308 & 66.748 \\
\hline Extractionyyyyyyyyyy \\
\hline
\end{tabular}


The significant KMO coefficient means that factor analysis is appropriate. Bartlett test has statistical significance (Sig. $<0.05$ ): This is a statistical quantity used to consider the hypothesis that variables do not correlate in the population. If this test is statistically significant (Sig. $<0.05$ ), the observed variables are correlated in the population. Thus, the variables are valid for factor analysis [76].

Table 4. KMO and Bartlett's Test

\begin{tabular}{|l|l|r|}
\hline \multicolumn{2}{|l|}{$\begin{array}{l}\text { Kaiser-Meyer-Olkin Measure of Sampling } \\
\text { Adequacy. }\end{array}$} & .943 \\
\hline \multirow{3}{*}{$\begin{array}{l}\text { Bartlett's Test of } \\
\text { Sphericity }\end{array}$} & Approx. Chi-Square & 9042.288 \\
\cline { 2 - 3 } & df & 1081 \\
\cline { 2 - 3 } & Sig. & .000 \\
\hline
\end{tabular}

Factor loading (factor loading factor or factor weight) is the criterion to ensure the practical significance of factor analysis: Factor loading $>0.3$ is considered to be the minimum level; Factor loading $>0.4$ is considered necessary; Factor loading $>0.5$ is considered to be of practical significance. Chart 6 shows that the factor loading of all variables is more significant than 0.6, which means that the factor analysis is valid [38].

Table 5. Rotated Component Matrix

\begin{tabular}{|c|c|c|c|c|c|c|c|c|}
\hline \multicolumn{9}{|c|}{ Rotated Component Matrix } \\
\hline & & & & Comp & & & & \\
\hline & 1 & 2 & 3 & 4 & 5 & 6 & 7 & 8 \\
\hline Openness 3 & .719 & & & & & & & \\
\hline Openness6 & .706 & & & & & & & \\
\hline Openness 1 & 697 & & & & & & & \\
\hline Openness 8 & .694 & & & & & & & \\
\hline Openness9 & .693 & & & & & & & \\
\hline Openness2 & .688 & & & & & & & \\
\hline Openness5 & .665 & & & & & & & \\
\hline Openness 4 & .644 & & & & & & & \\
\hline Openness 10 & .611 & & & & & & & \\
\hline Openness7 & .599 & & & & & & & \\
\hline Achievement1 & & .759 & & & & & & \\
\hline Achievement5 & & .759 & & & & & & \\
\hline Achievement6 & & .749 & & & & & & \\
\hline Achievement3 & & .746 & & & & & & \\
\hline Achievement4 & & .737 & & & & & & \\
\hline Achievement2 & & .724 & & & & & & \\
\hline Extraversion6 & & & .761 & & & & & \\
\hline Extraversion3 & & & .760 & & & & & \\
\hline Extraversion2 & & & .734 & & & & & \\
\hline Extraversion5 & & & .733 & & & & & \\
\hline Extraversion 4 & & & .682 & & & & & \\
\hline Extraversion1 & & & .675 & & & & & \\
\hline Worry4 & & & & .808 & & & & \\
\hline Worry3 & & & & .806 & & & & \\
\hline Worry2 & & & & .803 & & & & \\
\hline Worry5 & & & & .785 & & & & \\
\hline Worry1 & & & & .760 & & & & \\
\hline Power3 & & & & & .812 & & & \\
\hline Power2 & & & & & .802 & & & \\
\hline Power4 & & & & & .802 & & & \\
\hline
\end{tabular}




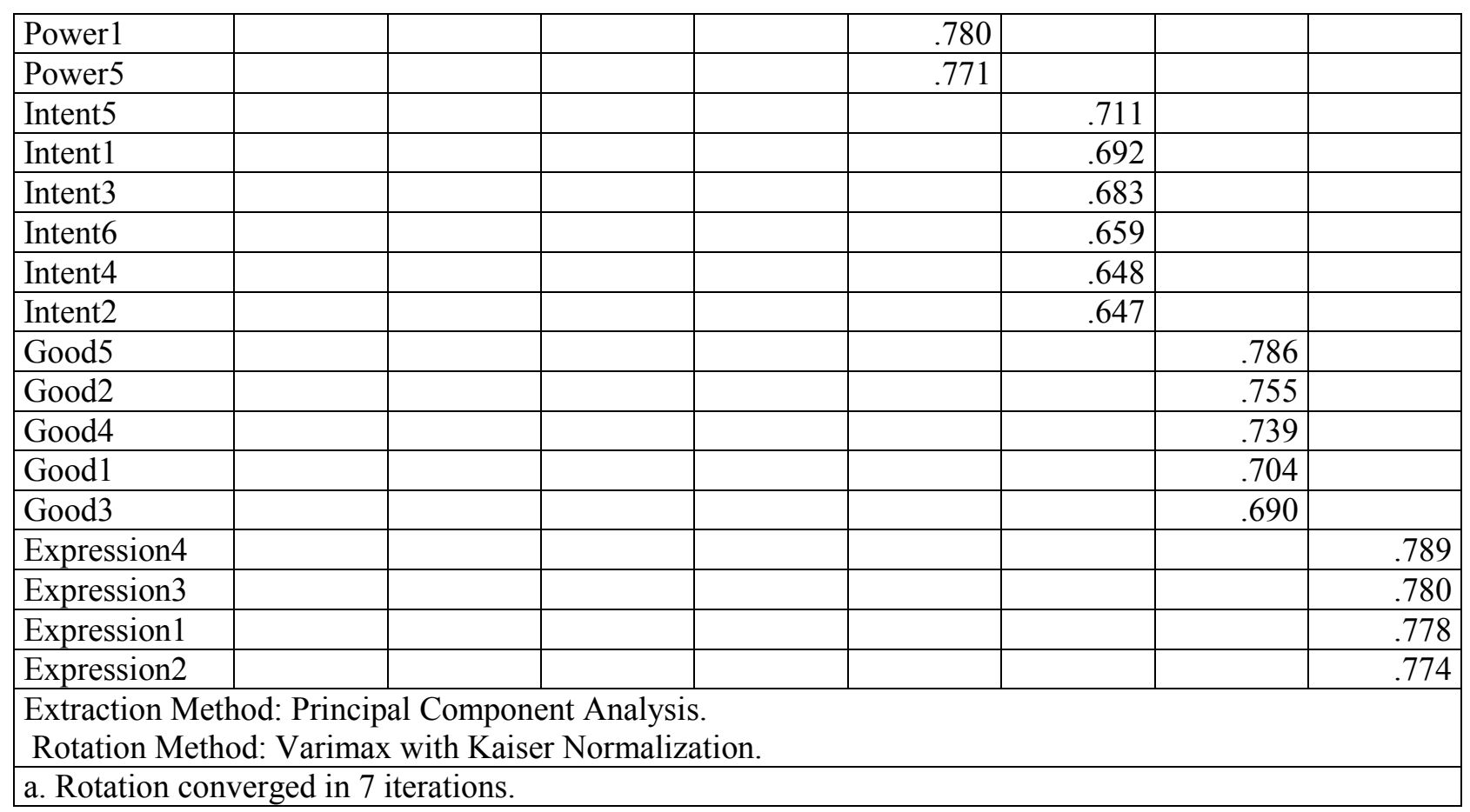

\subsection{Structural Equation Modeling (SEM)}

With the confirmatory factor analysis (CFA) technique, the SEM model allows the flexibility to find the most suitable model in the proposed models [21], [51], [58], [69], [95].

Evaluate the fit of the SEM model, Chi-Square $\left(\chi^{2}\right)$ testing, Root-Mean-Square Error of Approximation (RMSEA) procedures [10] together with confidence intervals, standardized-root are required. -mean square residual (SRMR), TuckerLewis Index (TLI) [93] and Comparative Fit Index (CFI) [7] were reported. It is suggested that a good fitting model should have values of CFI and TLI $\geq$ .90, RMSEA and SRMR $\leq .08$ [10], [15], [42], [51]. The SEM model is used to test the hypotheses posed in this article:

\subsection{SEM Model of the Relationship between Emigration Personality and Attitude Towards Money}

The results of SEM analysis (Figure 1) show that migration personality (openness and extraversion) positively and significantly affects attitudes towards money (money is a success, money is power, money is good). Money is alluring). It is worth noting that openness affects the attitude that money is good with Regression Weights $=0.421$ with confidence $p$-value $=0.000$. Openness affects the attitude that money is attractive with Regression Weights $=0.441$ with confidence $\mathrm{p}$ value $=0.000$ (Chart 6). Similarly, extraversion personality positively and significantly affects the attitude that money is power with Regression Weights $=0.503$ with confidence $\mathrm{p}$-value $=0.000$. Extraversion personality affects the attitude that money is attractive with Regression Weights = 0.499 with confidence $\mathrm{p}$-value $=0.000$. Extraversion personality affects the attitude that money is successful with Regression Weights = 0.411 with confidence $\mathrm{p}$-value $=0.000$. 
Fig. 1: SEM model of the relationship between emigration personality and attitude towards money

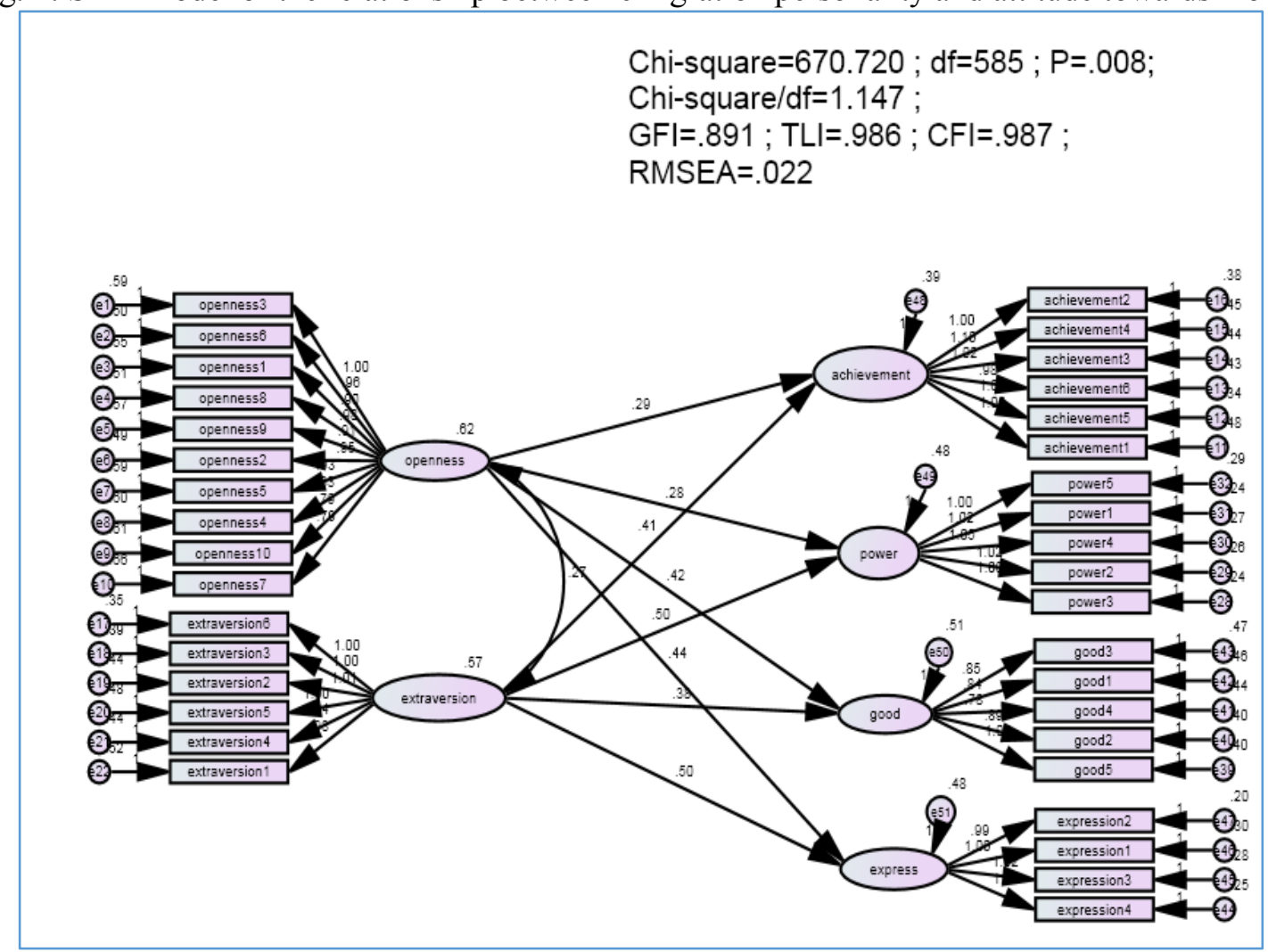

Table 6. Regression Weights relationship between personality and attitude towards money

\begin{tabular}{|l|l|l|r|r|r|r|l|}
\hline & & & Estimate & S.E. & C.R. & P & \\
\hline Achievement & $<---$ & Openness & .295 & .065 & 4.515 & $* * *$ & accept \\
\hline Power & $<---$ & Openness & .281 & .068 & 4.105 & $* * *$ & accept \\
\hline Good & $<---$ & Openness & .421 & .077 & 5.442 & $* * *$ & accept \\
\hline Express & $<---$ & Openness & .441 & .073 & 6.026 & $* * *$ & accept \\
\hline Achievement & $<---$ & Extraversion & .411 & .070 & 5.852 & $* * *$ & accept \\
\hline Power & $<---$ & Extraversion & .503 & .075 & 6.732 & $* * *$ & accept \\
\hline Good & $<---$ & Extraversion & .379 & .079 & 4.820 & $* * *$ & accept \\
\hline Express & $<---$ & Extraversion & .499 & .076 & 6.581 & $* * *$ & accept \\
\hline
\end{tabular}

About model fit: The analysis results (Figure 1) show that Chi-square $=1.147 ; \quad \mathrm{Df}=583 ; \quad \mathrm{P}-$ value $=0.08 ; \quad$ Chi-square $/ \mathrm{df}=1.258 ; \quad \mathrm{GFI}=0.899$; $\mathrm{TLI}=0.986 ; \mathrm{CFI}=0.987$; RMSEA $=0.022$. Thus, all coefficients meet the requirements. Particularly for GFI coefficients approximately 0.9 is acceptable [10], [93], [7], [15], [42], [51].

With the above analysis results, hypothesis $\mathrm{H} 1$ has been accepted. It means that emigration personality has a positive and significant impact on attitudes towards money.

\subsection{SEM Model of the Relationship between Emigration Personality and Intention to Join Illegal Labour Abroad}

The results of the SEM analysis (Figure 2) show that migration personality (openness and extraversion) positively and significantly affects the intention to engage in illegal labour abroad. It is noteworthy that openness affects the intention to join illegal labour abroad with the coefficient of Regression Weights $=0.490$ with the confidence $\mathrm{p}$ value $=0.000$ (Chart 8$)$. 
Fig. 2: SEM model of the relationship between personality and intention to join illegal labor abroad

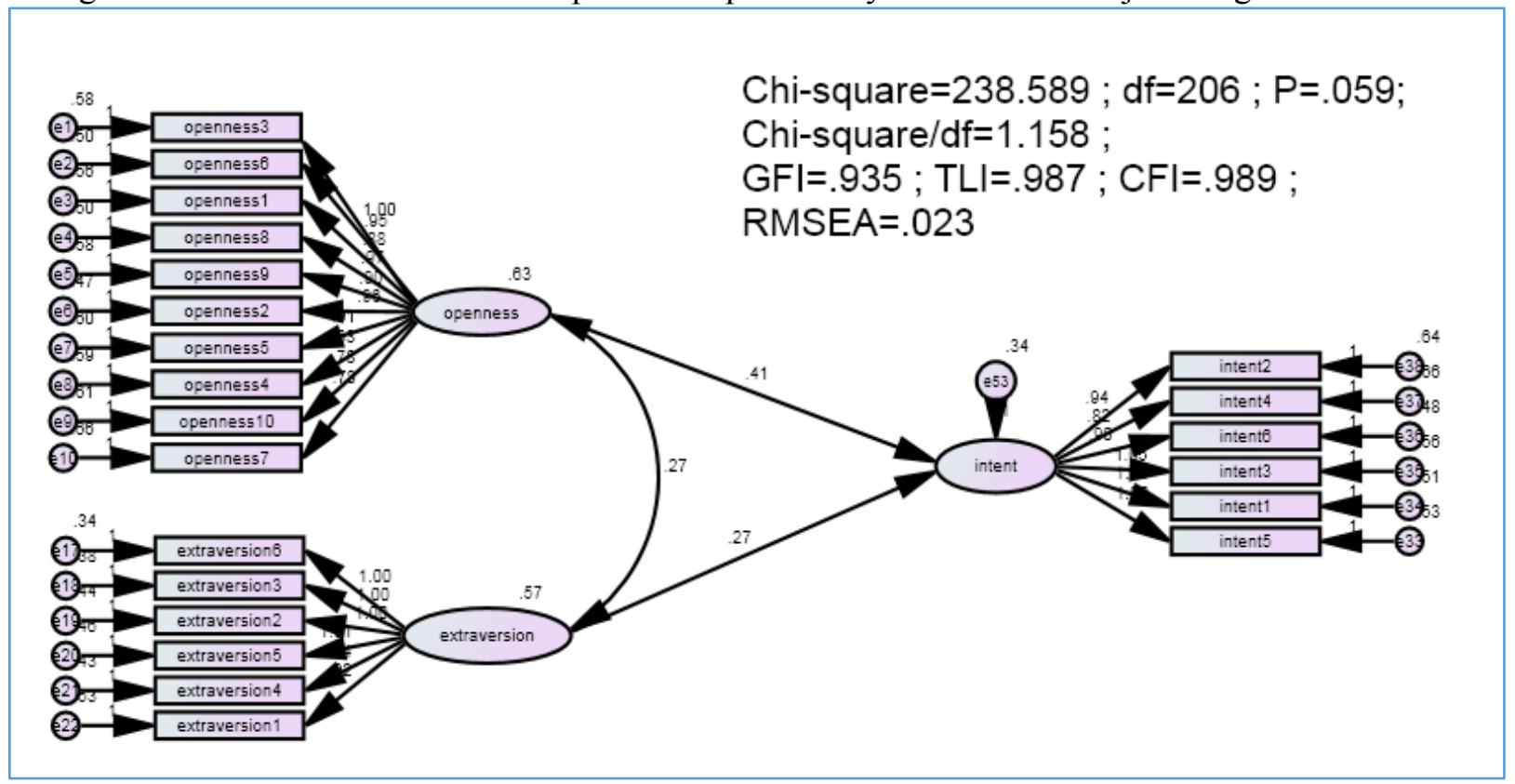

Table 7 . Regression Weights: Relationship between emigration personality and intention to participate illegal workers abroad

\begin{tabular}{|l|l|l|r|r|r|r|l|}
\hline & & & Estimate & S.E. & C.R. & P & \\
\hline Intent & $<---$ & Openness & .409 & .068 & 6.025 & $* * *$ & accept \\
\hline Intent & $<---$ & Extraversion & .267 & .066 & 4.056 & $* * *$ & accept \\
\hline
\end{tabular}

About model fit: Analysis results (Figure 2) for Chi-square $=238,589$; $\mathrm{Df}=206$; P-value $=0.059$; Chisquare/df $=1.158 ; \quad$ GFI $=0.935 ; \quad$ TLI $=0.987$; $\mathrm{CFI}=0.989$; RMSEA $=0.023$. Thus, the coefficients are satisfactory [10], [93], [7], [15], [42], [51]. With the above analysis results, hypothesis $\mathrm{H} 2$ has been accepted. It means that migrant personality has a positive and significant impact on engaging in illegal work abroad.

\subsection{SEM Model of the Relationship between Personality and Financial Anxiety}

The results of the SEM analysis (Figure 3) show that migration personality (openness and extraversion) has a positive and significant impact on financial anxiety. Openness affects financial anxiety with Regression Weights $=0.382$ with confidence P-value $=0.000$. Extraversion personality affects financial anxiety with Regression Weights $=0.397$ with confidence Pvalue $=0.000($ chart 8$)$. 
Fig. 3: SEM model of the relationship between emigration personality and financial anxiety

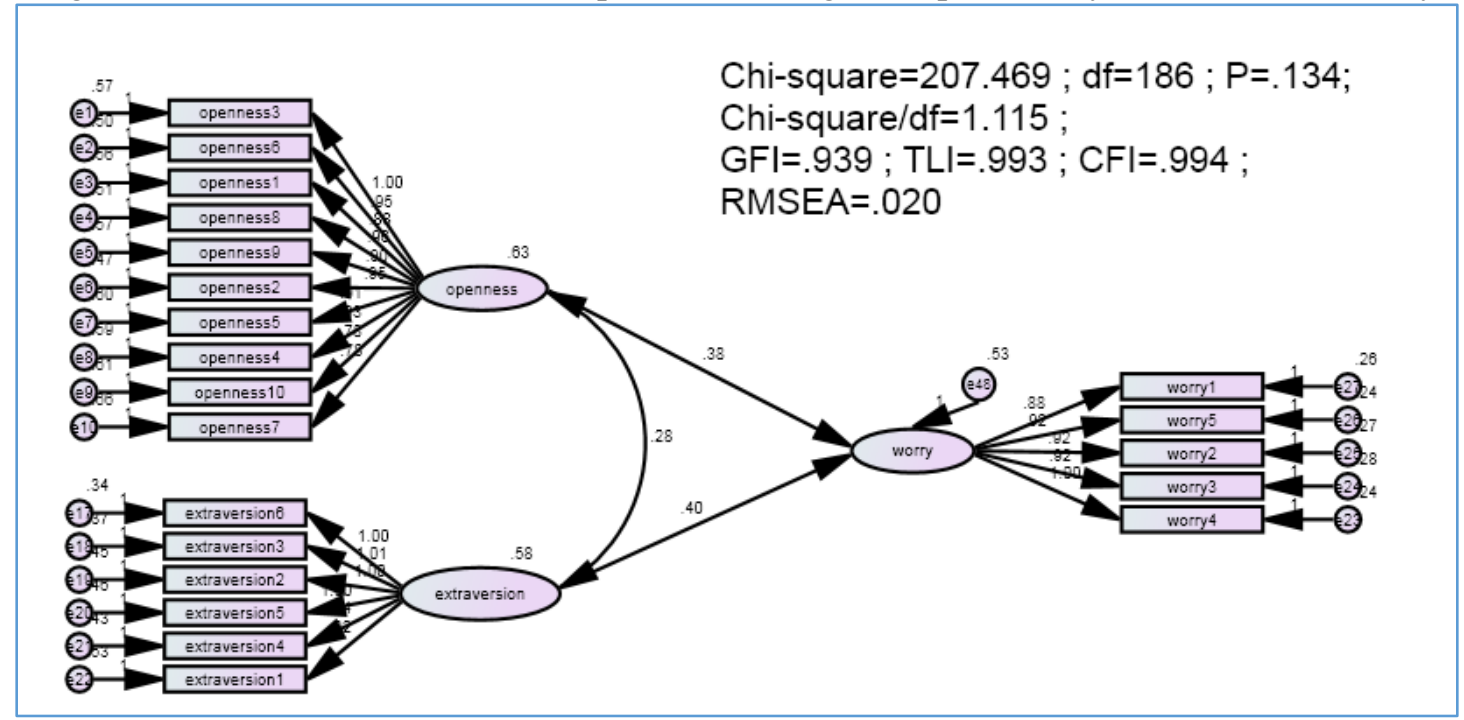

Table 8. Regression Weights on the relationship between emigration personality and financial anxiety

\begin{tabular}{|l|l|l|r|r|r|r|l|}
\hline & & & Estimate & S.E. & C.R. & P & \\
\hline Worry & $<---$ & Openness & .382 & .073 & 5.219 & $* * *$ & Accept \\
\hline Worry & $<---$ & Extraversion & .397 & .076 & 5.210 & $* * *$ & Accept \\
\hline
\end{tabular}

About model fit. Analysis results (Figure 3) for Chi-square $=207,469 ; \mathrm{Df}=186 ; \mathrm{P}$-value $=0.134$; Chisquare/df $=1.115 ; \quad$ GFI $=0.939 ; \quad$ TLI $=0.993$; $\mathrm{CFI}=0.994$; RMSEA $=0.020$. Thus, the coefficients are satisfactory [10], [93], [7], [15], [42], [51].

With the above analysis results, hypothesis $\mathrm{H} 3$ has been accepted. It means that emigration has a positive and significant effect on financial anxiety.

\subsection{SEM Model of the Relationship between Attitude Towards Money and Intention to Engage in Illegal Labour Abroad}

The results of the SEM analysis (Figure 4) show that the degree to money has a positive and significant effect on the intention to engage in illegal work abroad. It is worth noting that the attitude that money is power affects the intention to join illegal labour abroad with the coefficient of Regression Weights $=0.229$ with the reliability $\mathrm{p}$ value $=0.000$ (chart 10).

Fig. 4: SEM model of the relationship between attitude towards money and intention to engage in illegal labor abroad

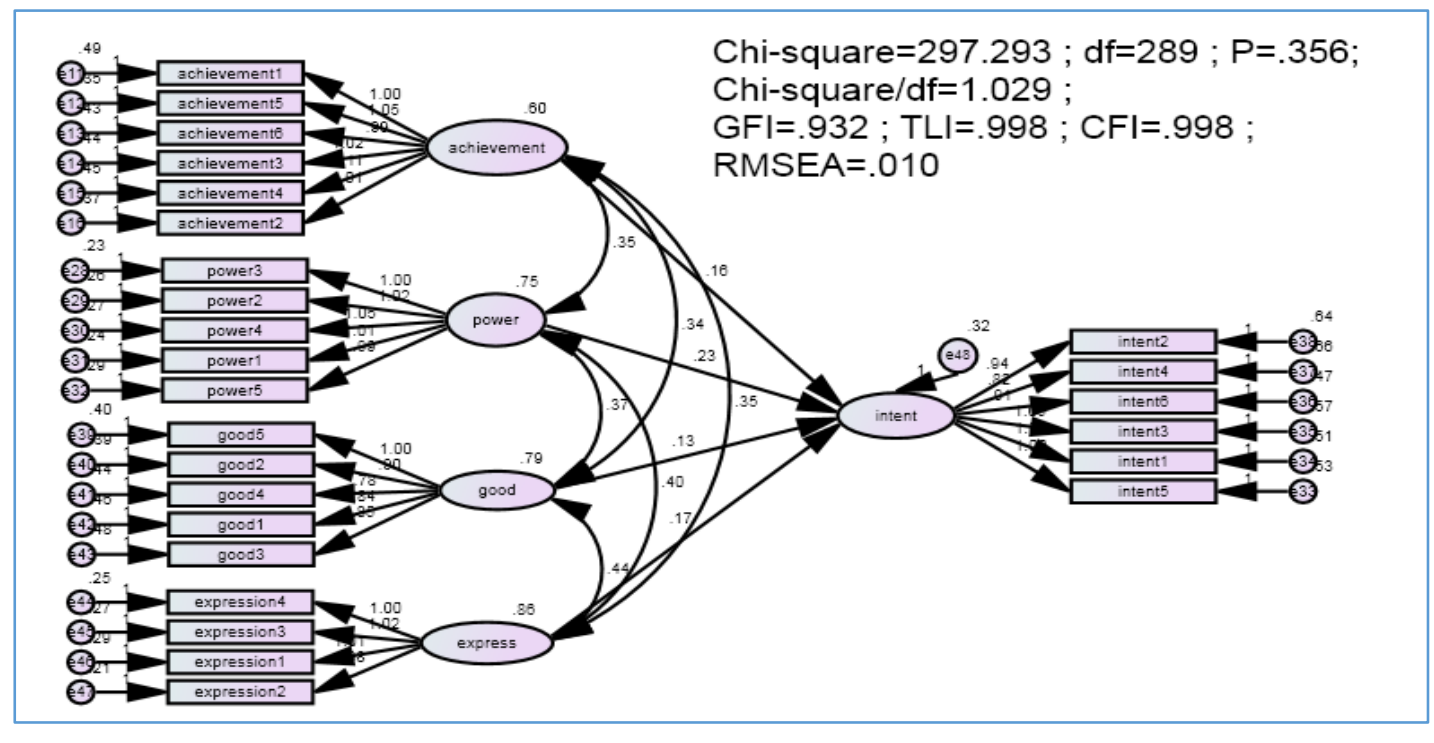


Table 9. Regression Weights on the relationship between attitude towards money and intention to engage in illegal work abroad

\begin{tabular}{|l|l|l|r|r|r|r|l|}
\hline & & & Estimate & S.E. & C.R. & P & \\
\hline Intent & $<---$ & Achievement & .159 & .068 & 2.317 & .020 & Accept \\
\hline Intent & $<---$ & Power & .229 & .061 & 3.771 & $* * *$ & Accept \\
\hline Intent & $<---$ & Good & .129 & .061 & 2.111 & .035 & Accept \\
\hline Intent & $<---$ & Express & .171 & .057 & 3.021 & .003 & Accept \\
\hline
\end{tabular}

About model fit. Analysis results (Figure 4) for Chi-square $=297.293$; Df $=289$; P-value $=0.356$; Chisquare $/ \mathrm{df}=1.029 ; \quad$ GFI $=0.932 ; \quad \mathrm{TLI}=0.998$; $\mathrm{CFI}=0.998$; RMSEA $=0.010$. Thus, the coefficients are satisfactory [10], [93], [7], [15], [42], [51].

With the above analysis results, hypothesis $\mathrm{H} 4$ was accepted. The attitude towards money positively and significantly affects the intention to engage in illegal work abroad.

\subsection{SEM Model of the Relationship between Financial Anxiety and Intention to Engage in Illegal Work Abroad}

The results of SEM analysis (Figure 5) show that financial anxiety has a positive and significant impact on the intention to join illegal labour abroad with Regression Weights $=0.401$ with confidence. $\mathrm{P}$-value $=0.000$ (Chart 10).

Fig. 5: SEM model of the relationship between financial anxiety and intention to engage in illegal work abroad

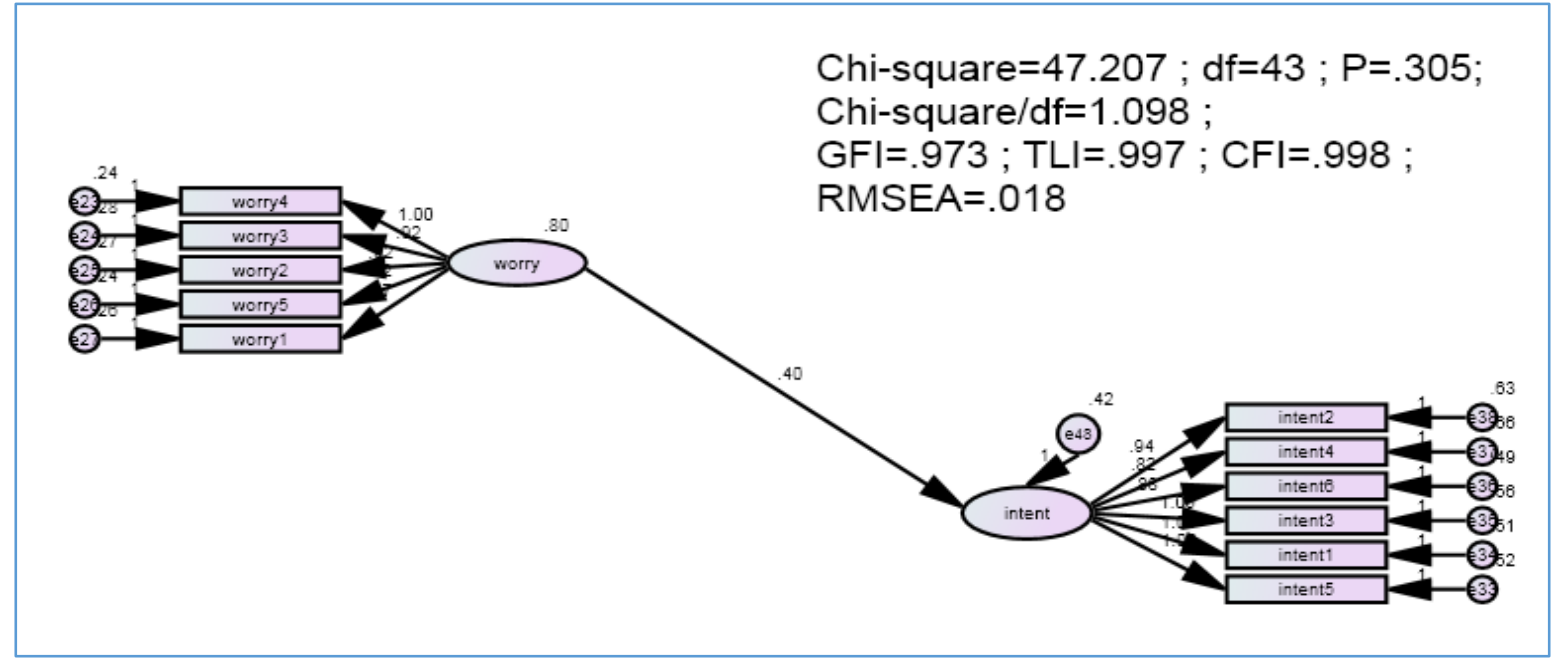

Table 10. Regression Weights on the relationship between financial anxiety and intention to engage in illegal work abroad

\begin{tabular}{|l|l|l|r|r|r|r|l|}
\hline & & & Estimate & S.E. & C.R. & P & \\
\hline Intent & $<---$ & Worry & .401 & .055 & 7.295 & $* * *$ & Accept \\
\hline
\end{tabular}

About model fit. Analysis results (Figure 5) for Chi-square $=47,207$; $\mathrm{Df}=43$; P-value $=0.305$; Chisquare/df $=1.098 ; \quad$ GFI $=0.973 ; \quad$ TLI $=0.997$; CFI $=0.998$; RMSEA $=0.018$. Thus, the coefficients are satisfactory[10], [93], [7], [15], [42], [51].

With the above analysis results, hypothesis $\mathrm{H} 5$ was accepted. It means that financial anxiety has a positive and significant effect on engaging in illegal work abroad.

\subsection{SEM Model of the Relationship between Personality, Money Consciousness, Financial Anxiety and Intention to Join Illegal Work Abroad}

After performing the testing procedures for different SEM models, we choose the overall model based on the model fit-testing indicators (Figure 6). The results of the SEM analysis (Figure 6) show that personality, attitude towards money, and financial anxiety have a positive and significant impact on the intention to engage in illegal work abroad. The high impact including openness personality affects the degree that money is good 
with Regression Weights $=0.423$ and reliability $\mathrm{p}$ value $=0.000$; Money is impressive with Regression Weights $=0.443$ and reliability $\mathrm{p}$-value $=0.000$, extraversion personality affects the attitude of money as power with Regression Weights $=0.503$ and confidence p-value $=0.000 ;$ money is successful with coefficient Regression Weights $=$ 0.412 and reliability $p$-value $=0.000$; Money is impressive with coefficient of Regression Weights = 0.499 and reliability $\mathrm{p}$-value $=0.000$, financial anxiety affects intention to join illegal work abroad with Regression Weights $=0.421$ and reliability $\mathrm{p}$ value $=0.000$ (Chart 11).

About model fit: The analysis results (Figure 6) show that Chi-square $=1201,715 ; \mathrm{Df}=1020 ; \mathrm{P}$ value $=000 ; \quad$ Chi-square $/ \mathrm{df}=1.178 ; \quad \mathrm{GFI}=0.861$; $\mathrm{TLI}=0.977$; $\mathrm{CFI}=0.979$; RMSEA $=0.024$. Thus, the coefficients are satisfactory [10], [93], [7], [15], [42], [51].

Fig. 6: Overall SEM model of the relationship between personality, money consciousness, financial anxiety and intention to join illegal labor abroad

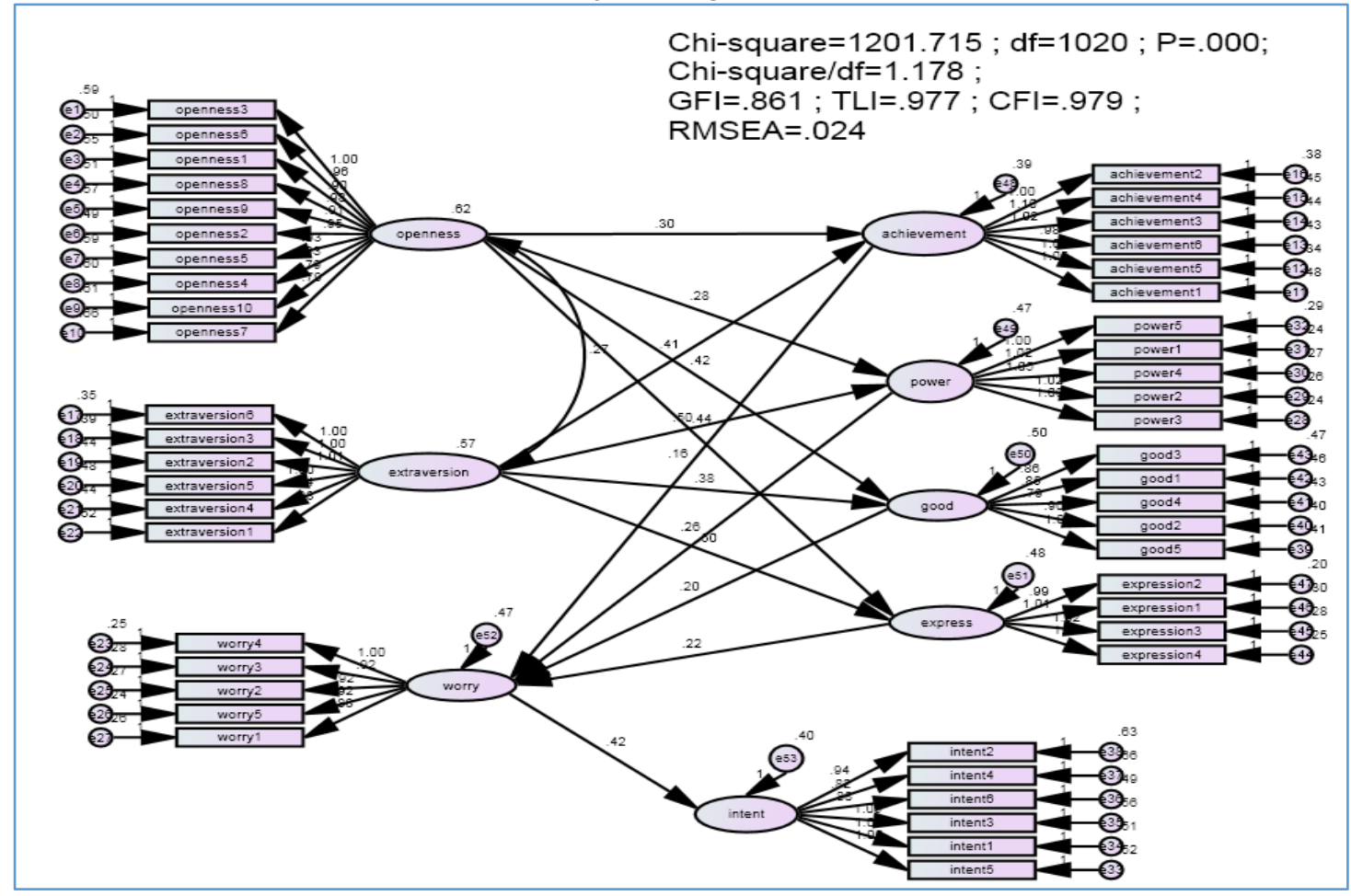

Table 11. Regression Weights on the relationship between personality, money sense, financial anxiety and intention to join illegal work abroad

\begin{tabular}{|l|l|l|r|r|r|r|l|}
\hline & & & Estimate & S.E. & C.R. & P & \\
\hline Achievement & $<---$ & Openness & .297 & .065 & 4.546 & $* * *$ & accept \\
\hline Power & $<---$ & Openness & .283 & .068 & 4.147 & $* * *$ & accept \\
\hline Good & $<---$ & Openness & .423 & .077 & 5.507 & $* * *$ & accept \\
\hline Express & $<---$ & Openness & .443 & .073 & 6.071 & $* * *$ & accept \\
\hline Achievement & $<---$ & Extraversion & .412 & .070 & 5.867 & $* * *$ & accept \\
\hline Power & $<---$ & Extraversion & .503 & .074 & 6.749 & $* * *$ & accept \\
\hline Good & $<---$ & Extraversion & .377 & .078 & 4.837 & $* * *$ & accept \\
\hline Express & $<---$ & Extraversion & .499 & .076 & 6.599 & $* * *$ & accept \\
\hline Worry & $<---$ & Achievement & .162 & .068 & 2.388 & .017 & accept \\
\hline Worry & $<---$ & Power & .261 & .060 & 4.325 & $* * *$ & accept \\
\hline Worry & $<---$ & Good & .201 & .061 & 3.295 & $* * *$ & accept \\
\hline worry & $<---$ & express & .220 & .058 & 3.796 & $* * *$ & accept \\
\hline intent & $<---$ & worry & .424 & .057 & 7.498 & $* * *$ & accept \\
\hline
\end{tabular}




\section{Discussion}

\subsection{Key Findings}

First, the study found a positive and significant association between emigration (extraversion and openness) and attitudes towards money. Migrants want money, they want success, they want power, and they want to be charismatic. Migrants will use money as a means to impress others and gain social recognition. Migrants love money, want to use the money to show power, improve self-esteem, and expect to be recognized by others. This finding is similar to that of [100], [82], [102].

Second, the study found a positive and significant association between emigration personality and intention to engage in illegal work abroad. It means that people with a migrant personality are likely to engage in illegal work abroad to a high degree. People with a highly persistent migrant personality tend to seek out new experiences and are likely to join the illegal labour force abroad without opportunities. It is similar to the findings of [80], [81], [62], [44] that people with a migratory personality have a solid intention to migrate and tend to migrate, and they are seeking new experiences in their destination. It is similar to [81], [33] that people with a migratory personality and a thirst for adventure have the necessary persistence to undertake migration successfully. Moreover, this also coincides with the finding of [14] that people with an open and migratory personality have strong adaptive skills and influence on migration, so they are more likely to participate in the migration process illegal workers abroad.

Third, the study found a positive and significant association between emigration personality and financial anxiety. It means that people with a migratory personality are likely to have high financial aspirations. They are more likely to join illegal labour abroad to relieve their current financial worries. It is similar to the finding of [4], [14] that there exists a relationship between accounting for migration decisions and economic prospects. That is, the purpose of migration is to open up the possibility of making more money. The Vietnamese people involved in illegal work abroad are primarily young and middle-aged. This age group is in the group that worries about finances to cover family expenses and personal future. It is similar to the finding by [99] that financial anxiety is mentioned more often by young and middle-aged people. It is similar to the findings of [41] that ability to: handle financial emergencies, ability to meet basic needs, debt level, savings and money for future financial needs and life goals Many
Vietnamese people want to settle abroad because they are not satisfied with their current life, the focus is on financial issues. Similar to Yamauchi, Templer's (1982) finding that individuals use money as a means to plan and prepare for the future. In Vietnam, there is a fact, as found by [89], [30] that poverty remains high, and the land falls into state hands in rural Vietnam. The interviewees explained that their intentions stem from the fact that the quality of life in Vietnam is not good enough. It is similar to [90] finding that some interviewees implied they were dissatisfied with political issues and social injustices in Vietnam, so immigration through the pursuit of International education is a viable option.

Fourth, the study found a positive and significant association between attitudes towards money and intention to engage in illegal work abroad. It means that money-loving, money-focused people are more likely to engage in illegal labour abroad. It is similar to the finding of [100] that money-loving individuals use money as a means to impress others and gain social recognition. Money-centres argue that using the money for social comparison, powerseeking, ostentatiousness, and overcoming selfdoubt leads to low subjective happiness [24], [77]. People who love money, focus on money are often not satisfied or less satisfied with their current job, current compensation and salary. They aspire to migrate to look for a new job and position to get more money. It is similar to [82] finding that people who emphasize money as an indicator of their performance may have low satisfaction with their current job, promotion, supervision. Coworkers and overall life satisfaction. The ability to engage in illegal labour of money-loving, moneycentred people is highly likely to engage in illegal labour because they have a strong desire for money. They have expectations of having the opportunity to earn much money when their current position and job prevent them from getting this. It is similar to the finding of [72] that people who value money have a stronger desire than others for wealth and can therefore be expected to work more or strive for higher jobs with higher-paying jobs.

Fifth, the study discovered a positive and significant relationship between financial anxiety and intention to engage in illegal work abroad. It means that people with financial worries are more likely to engage in illegal work abroad. It is similar to [67] findings that financial satisfaction is an integral component of overall life satisfaction and 
happiness. Similar to [89] finding that many Vietnamese people want to settle abroad because they are not satisfied with their current life, the focus is on financial issues. Similar to [30] finding that in the context of poverty and limited prospects, many individuals are willing to take risks to seize opportunities abroad to earn more. In poverty and limited prospects, many individuals are willing to take risks to seize opportunities abroad to earn more money. The prevailing notions of charm and opportunity in wealthy countries of stable employment, better living conditions, and access to hard currency seem to offer a way out of endless difficulty [30]. It sets the stage for human trafficking and illegal immigration, as people without legal immigration conditions depend on illegal intermediaries for passport purchases and transportation [30]. It involves human trafficking, forced labour, and slavery [30].

Sixth, the study explored a reliable and significant causal relationship between emigration personality, attitude towards money, financial anxiety and intention to engage in illegal labour in the country. It means that migration personality has a positive and significant impact on attitude towards money, attitude towards money has a positive and significant impact on financial anxiety, financial anxiety. have a positive and significant effect on the intention to engage in illegal labour.

\section{Limitations}

As with other empirical studies, there are limitations to this study that should be considered when discussing the results.

Firstly, the paper and pencil survey method was used in our study. It reflects the subjective perception of the respondents towards the investigated questions. Therefore, the data is still subjective of the respondents [63]. Furthermore, our data is collected over a single period.

Second, this study explores the relationship between personality, attitude towards money, financial anxiety and intention to engage in illegal work abroad. Some other factors have been ignored, such as differences in demographic factors such as gender, income. It is also possible to evaluate the influencing factors for the intention to engage in illegal labour law abroad through the theory of planned behaviour, reasoned action [63]. Future studies should also assess the impact of additional factors not included in our analysis, such as current living conditions, information factors, poverty factors, and unemployment. Our research was done in a Vietnamese cultural context. Studying in other cultural contexts and drawing generalized conclusions by research develops a different research paradigm [79].

\section{Conclusions}

In recent years, the number of Vietnamese people joining the illegal labour force abroad has been increasing. However, some studies have only found the factors affecting the intention to join illegal work abroad by qualitative research. In order to fill the research gap on Vietnamese people's intention to join illegal work abroad, this study used quantitative research methods. It used theories of personality, attitudes about money, financial anxiety as a framework for understanding standard views on intentions to engage in illegal work abroad detail: About model fit: Analysis results (Figure 2) for Chisquare $=238,589 ; \quad \mathrm{Df}=206 ; \quad \mathrm{P}$-value $=0.059$; Chisquare $/ \mathrm{df}=1.158 ; \quad \mathrm{GFI}=0.935 ; \quad \mathrm{TLI}=0.987$; $\mathrm{CFI}=0.989$; RMSEA $=0.023$. Figure 3 for $\mathrm{Chi}-$ square $=207,469 ; \mathrm{Df}=186 ; \mathrm{P}$-value $=0.134 ; \mathrm{Chi}-$ square $/ \mathrm{df}=1.115 ; \quad \mathrm{GFI}=0.939 ; \quad \mathrm{TLI}=0.993$; $\mathrm{CFI}=0.994$; RMSEA $=0.020$. Figure 4 for Chisquare $=297.293 ; \mathrm{Df}=289 ; \mathrm{P}$-value $=0.356$; Chisquare $/ \mathrm{df}=1.029 ; \quad$ GFI $=0.932 ; \quad$ TLI $=0.998$; $\mathrm{CFI}=0.998$; RMSEA $=0.010$. Figure 5 for Chisquare $=47,207 ; \mathrm{Df}=43 ; \mathrm{P}$-value $=0.305 ;$ Chisquare $/ \mathrm{df}=1.098 ; \quad$ GFI $=0.973 ; \quad$ TLI $=0.997$; $\mathrm{CFI}=0.998$; RMSEA $=0.018$. Figure 6 show that Chi-square $=1201,715 ; \quad \mathrm{Df}=1020 ; \quad \mathrm{P}$-value $=000$; Chi-square/df $=1.178 ; \quad$ GFI $=0.861 ; \quad$ TLI $=0.977$; CFI $=0.979$; RMSEA $=0.024$. Research results show that emigration personality has a positive and significant impact on attitude towards money, attitude towards money has a positive and significant impact on financial anxiety. Financial anxiety has a positive and significant effect on the intention to engage in illegal work abroad. These findings have contributed to enriching the research literature on intentions to engage in illegal labour. The conclusions of this study provide helpful information for Vietnamese government policymakers. It should be recalled that the sample size in this study was small; therefore, it would be beneficial to repeat this study using a larger sample group from a more diverse population.

\section{References:}

[1] AFP. (2019). Bored and broke, Vietnam migrants risk lives for riches in Europe. Bored and broke, Vietnam migrants risk lives for riches in Europe. https://www.bangkokpost.com/world/178089 
4/bored-and-broke-vietnam-migrants-risklives-for-riches-in-europe

[2] Ajzen, I. (1987). Attitudes, traits, and actions: dispositional prediction of behavior in personality and social psychology. Adv Exp Soc Psychol 20(1); pp1-63

[3] Almlund, M., Duckworth, A. L., Heckman, J., \& Kautz, T. (2011). Personality psychology and economics. In E. A. Hanushek, S. Machin, \& L. Woessmann (Eds.), Handbook of the Economics of Education, (Vol. 4, pp. 1-181): Elsevier.

[4] Ayhan, S., Gatskova, K., \& Lehmann, H. (2017). The impact of non-cognitive skills and risk preferences on rural-to-urban migration: Evidence from Ukraine. IZA Discussion Paper Series No.10982.

[5] Bauernschuster, S., Falck, O., Heblich, S., Suedekum, J., \& Lameli, A. (2014). Why are educated and risk loving persons more mobile across regions? Journal of Economic Behavior \& Organization, 98, 56-69.

[6] Belot, M., \& Ederveen, S. (2012). Cultural barriers in migration between OECD countries. Journal of Population Economics, 25(3), 1077-1105.

[7] Bentler, P. M. (1990). Comparative fit indexes in structural models. Psychological Bulletin,107, 238-246. https://doi.org/10.1037/0033-295X.86.5.452

[8] Bertoli, S., Fernández-Huertas Moraga, J., \& Ortega, F. (2013). Crossing the border: Selfselection, earnings and individual migration decisions. Journal of Development Economics, 101, 75-91.

[9] Borghans, L., Duckworth, A. L., Heckman, J. J., \& Weel, B. t. (2008). The economics and psychology of personality traits. Journal of Human Resources, 43(4), 972-1059.

[10] Brown, L. (2002). Sex Slaves: The trafficking of women in Asia. London: Virago Press.

[11] Browne, M. W., \& Cudeck, R. (1993). Alternative ways of assessing model fit. In K. A.Bollen \& J. S. Long (Eds.). Testing structural equation models (pp. 136-162). Newbury Park,CA: Sage.

[12] Brunner, M. \& Süß, H. (2005). Analyzing the Reliability of Multidimensional Measures: An Example from Intelligence Research. Retrieved May 16, 2019 from: http://citeseerx.ist.psu.edu/viewdoc/downloa $\mathrm{d}$ ?doi=10.1.1.856.4612\&rep=rep1\&type $=$ pdf

[13] Burchell, B. J. (2003). Identifying, describing and understanding financial aversion: Financial phobes. Report for EGG. Retrieved from http:// people.pwf.cam.ac.uk/bb101/FinancialAvers ion ReportBurchell.pdf

[14] Butikofer, A., \& Peri, G. (2017). Cognitive and noncognitive skills and the selection and sorting of migrants. National Bureau of Economic Research Working Paper Series, No. 23877.

[15] Byrne, B. M. (1989). A primer of LISREL: Basic applications and programming for confirmatory factor analytic models. New York: Springer. https://doi.org/10.1007/9781-4613-8885-2

[16] Camperio Ciani, A. S., Capiluppi, C., Veronese, A., \& Sartori, G. (2007). The adaptive value of personality differences revealed by small island population dynamics. European Journal of Personality, 21(1), 3-22.

[17] Canache, D., Hayes, M., Mondak, J. J., \& Wals, S. C. (2013). Openness, extraversion and the intention to emigrate. Journal of Research in Personality, 47(4), 351-355.

[18] Cerny, C.A., \& Kaiser, H.F. (1977). A study of a measure of sampling adequacy for factor-analytic correlation matrices. Multivariate Behavioral Research, 12(1), 4347.

[19] Claes Fornell and David F. Larcker. Evaluating Structural Equation Models with Unobservable Variables and Measurement Error. Journal of Marketing Research, Vol. 18, No. 1 (Feb., 1981), pp. 39-50

[20] Cortina, J. M. (1993). What is coefficient alpha? An examination of theory and applications. Journal of applied psychology, 78(1), 98.

[21] Crowley, S. L., \& Fan, X. (1997). Structural equation modeling: Basic concepts and applications in personality assessment research. Journal of Personality Assessment, 68(3), 508-531. https://doi.org/10.1207/s15327752jpa6803_4

[22] Czaika, M. (2012). Migration in times of uncertainty: on the role of economic prospects. DEMIG project paper no. 11. International Migration Institute.

[23] David Nguyen.(2019). The number of Vietnamese who want to live abroad is still very high. [Vietnamese version]. https://www.bbc.com/vietnamese/forum46736513

[24] Diener, E. Suh, E. M., Lucas, R. E., \& Smith, H. L. (1999). Subjective well-being: Three 
decades of progress. Psychological Bulletin, 125(2), 276-302.

[25] Erdener, C., \& Garkavenko, V. (2012). Money attitudesin Kazakhstan. Journal of International Business and Economics, 12(3), 87-94.

[26] European Union, Consular Department Ministry of Foreign Affairs, International Organization for Migration (2011). An overview of the migration of Vietnamese citizens abroad. [Vietnamese version]. Hanoi: DNA Company

[27] Fawcett, J. T. (1985). Migration psychology: New behavioral models. Population and Environment, 8(1), 5-14.

[28] Finn, D.R. (1992), "The meaning of money a view from economists". American Behavioral Scientist, Vol. 35 No. 6, pp. 65868.

[29] Furnham, A. (1984), "Many sides of the coin: the psychology of money usage". Personality and Individual Differences, Vol. 5 No. 5, pp. 501-9.

[30] Gabriel Temesgen. Root Causes and Solutions to Human Trafficking in Ethiopia. International Journal of Science and Research (IJSR), August 2014.ISSN (Online): 2319-7064

[31] Garman, E. T., Leech, I. E., \& Grable, J. E. (1996). The negative impact of employee poor personal financial behaviors on employers. Financial Counseling and Planning, 7, 157-168.

[32] Gbadamosi, G., \& Joubert, P. (2005). Money ethic, moral conduct and work related attitudes: Field study from the public sector in Swaziland. Journal of Management Development, 24(8), 754-763.

[33] Gibson, J., \& McKenzie, D. (2011). The microeconomic determinants of emigration and return migration of the best and brightest: Evidence from the Pacific. Journal of Development Economics, 95(1), 18-29. doi: 10.1016/j. jdeveco.2009.11.002

[34] Goldberg, L. R. (1990). An alternative "description of personality": the big-five factor structure. Journal of Personality and Social Psychology, 59(6), 1216-1229.

[35] Gresham, A. and Fontenot, G. (1989), "The differing attitudes of the sexes toward money: an application of the money attitudes scale", in Gordon, P.J. and Kellerman, B.J. (Eds), Advances in Marketing, Southwestern Marketing Association, Charleston, SC, pp. 380-4.
[36] Groenewold, G., Bruijn, B., \& Bilsborrow, R. (2012). Psychosocial factors of migration: Adaptation and application of the health belief model. International Migration, 50(6), 211-231.

[37] Ha Thanh. (2019). 5.6\% of Vietnamese children show signs of being trafficked. https://tuoitre.vn/5-6-tre-em-viet-nam-codau-hieu-la-nan-nhan-buon-nguoi20190813125244917.htm

[38] Hair, J., Anderson, R., Tatham, R. and Black, W. (1998). Multivariate data analysis. 5th Edition, Prentice Hall, New Jersey.

[39] Hair, J., Black, W., Babin, B., and Anderson, R. (2010). Multivariate data analysis (7th ed.): Prentice-Hall, Inc. Upper Saddle River, NJ, USA.

[40] Hair.J., J. F., Black., W. C., Babin., B. J., Anderson.,R. E., \& L.Tatham., R. (2006). Multivariant Data Analysis. New Jersey: Pearson International Edition.

[41] Hira, T. K., \& Mugenda, O. M. (1998). Predictors of finan-cial satisfaction: Differences between retirees and nonretirees. Financial Counseling and Planning, 9(2), 75-83.

[42] Hu, L. T., \& Bentler, P. M. (1999). Cutoff criteria for fit indexes in covariance structure analysis: Conventional criteria versus new alternatives. Structural Equation Modeling: A Multidisciplinary Journal, 6(1), 1-55. https://doi.org/10.1080/10705519909540118

[43] John, O. P., \& Srivastava, S. (1999). The BigFive trait taxonomy: History, measurement, and theoretical perspectives. In L. A. Pervin \& O. P. John (Eds.), Handbook of personality: Theory and research (Vol. 2, pp. 102-138). New York: Guilford Press. (44item inventory that measures an individual on the Big Five Factors (dimensions) of personality (Goldberg, 1993). Each of the factors is then further divided into personality facets.)

[44] Jokela, M. (2009). Personality predicts migration within and between U.S. states. Journal of Research in Personality, 43(1), 79-83. doi: 10.1016/j.jrp.2008.09.005

[45] Jokela, M., Elovainio, M., Kivimăki, M., \& Keltikangas-Jarvinen, L. (2008). Temperament and migration patterns in Finland. Psychological Science, 19(9), 831837.

[46] Joo, S., \& Grable, J. (2004). An exploratory framework of the determinants of financial 
satisfaction. Journal of Family and Economic Issues, 25(1), 25-50.

[47] Joo, S., \& Grable, J. E. (2000). Improving employee productivity: The role of financial counseling and education. Journal of Employment Counseling, 37, 2-15.

[48] Joseph F. Hair Jr. William C. Black Barry J. Babin Rolph E. (2014). Anderson. Multivariate Data Analysis Seventh Edition. Pearson Education Limited

[49] Kahneman, D. (2011). Thinking, fast and slow. New York: Farrar, Strass and Giroux.

[50] Kaiser, H. (1974). An index of factor simplicity. Psychometrika 39: 31-36.

[51] Kline, R.B. (2011). Principles and Practice of Structural Equation Modeling. Guilford Press, New York

[52] Lange, C., \& Byrd, M. (1998). The relationship be-tween perceptions of financial distress and feelings of psychological wellbeing in New Zealand university students. International Journal of Adolescence and Youth, 7, 193-209.

[53] Le Thi Minh Phuong. (2018). The legal mechanism for the protection of Vietnamese citizens migrating abroad. Journal of Industry and Trade online. [Vietnamese version].

http://www.tapchicongthuong.vn/bai-viet/coche-phap-ly-ve-bao-ho-cong-dan-viet-namdi-cu-ra-nuoc-ngoai-53994.htm

[54] Lemrová, S., Reiterová, E., Fatěnová, R., Lemr, K., \& Tang, T. L. P. (2014). Money is power: Monetary intelligence-love of money and temptation of materialism among Czech university students. Journal of Business Ethics, 125(2), 329-348.

[55] Mara Bierbach. People smuggling from Vietnam to Europe: The facts. https://www.infomigrants.net/en/post/20423/ people-smuggling-from-vietnam-to-europethe-facts

[56] Mayda, A. M. (2010). International migration: a panel data analysis of the determinants of bilateral flows. Journal of Population Economics, 23(4), 1249-1274.

[57] Medina, J.F., Saegert, J. and Gresham, A. (1996), "Comparison of Mexican-American and Anglo-American attitudes toward money". The Journal of Consumer Affairs, Vol. 30 No. 1, pp. 124-45.

[58] Nachtigall, C., Kroehne, U., Funke, F., \& Steyer, R. (2003). (Why) should we use SEM? Pros and cons of structural equation modeling. Methods of Psychological Research Online, 8(2),1-22.

[59] Ngoc Le. (2010). BPSOS: Human trafficking lines are very 'sophisticated' and 'cruel'. [Vietnamese version]. https://www.voatiengviet.com/a/bpsos$\mathrm{c} \% \mathrm{C} 3 \% \mathrm{~A} 1 \mathrm{c}-\mathrm{d} \% \mathrm{C} 6 \% \mathrm{~B} 0 \% \mathrm{E} 1 \% \mathrm{BB} \% 9 \mathrm{Dng}$ d $\%$ C3\%A2y-bu\%C3\%B4nng\%C6\%B0\%E1\%BB\%9Dir\%E1\%BA\%A5t-tinh-vi-v\%C3\%A0t\%C3\%A0n-\%C3\%A1c-/5148943.html

[60] Nkundabanyanga, S. K., Omagor, C., Mpamizo, B., \& Ntayi, J. M. (2011). The Love of Money, pressure to Perform and Unethical Marketing Behavior in the Cosmetic Industry in Uganda. International Journal of Marketing Studies, 3(4), 40-49.

[61] Nunnally, J.C. and Bernstein, I.H. (1994) The Assessment of Reliability. Psychometric Theory, 3, 248-292.

[62] Otto, K., \& Dalbert, C. (2012). Individual differences in job-related relocation readiness: The impact of personality dispositions and social orientations. Career Development International, 17(2), 168-186. doi: 10.1108/13620431211225340

[63] Pakpour AH, Gellert P, Asefzadeh S, Updegraff JA, Molloy GJ, Sniehotta FF. Intention and planning predicting medication adherence following coronary artery bypass graft surgery. Journal of Psychosomatic Research. 2014; 77(4):287-95. https://doi.org/10.1016/j.jpsychores.2014.07. 001 PMID: 25280826

[64] Paulauskaite, E., Seibokaite, L., \& Endriulaitiene, A. (2010). Big five personality traits linked with migratory intentions in Lithuanian student sample. International Journal of Psychology: A Biopsychosocial Approach, 7, 41-58.

[65] Pedersen, P. J., Pytlikova, M., \& Smith, N. (2008). Selection and network effectsMigration flows into OECD countries 19902000. European Economic Review, 52(7), 1160-1186.

[66] Pham Hoat (2019). Illegal labor abroad: Do not gamble with fate. [Vietnamese version]. 30/10/2019. http://cand.com.vn/doisong/Lao-dong-ra-nuoc-ngoai-bat-hop-phapKhong-nen-danh-bac-voi-so-phan-567647/

[67] Plagnol, A. C. (2011). Financial satisfaction over the life course: The influence of assets and liabilities. Journal of Economic Psychology, 32(1), 45-64. 
[68] Raykov, T. (1997). Estimation of composite reliability for congeneric measures. Applied Psychological Measurement, 21(2), 173-184.

[69] Raykov, T., \& Marcoulides, G. (2006). A first course in structural equation modeling (2nd Ed.). Mahwah, NJ: Lawrence Erlbaum.

[70] Sardžoska, E., \& Tang, T. L. P. (2009). Testing a model of behavioral intentions in the Republic of Macedonia: Differences between the private and the public sectors. Journal of Business Ethics, 87(4), 495-517.

[71] Schaefer, P. S., Williams, C. C., Goodie, A. S., \& Campbell, W. K. (2004). Overconfidence and the Big Five. Journal of Research in Personality, 38(5), 473-480.

[72] Schor, J.B. (1991). The Overworked American: The Unexpected Decline of Leisure. New York: Basic Books.

[73] Silventoinen, K., Hammar, N., Hedlund, E., Koskenvuo, M., Ronnemaa, T., \& Kaprio, J. (2008). Selective international migration by social position, health behaviour and personality. European Journal of Public Health, 18(2), 150-155.

[74] Simmel, G. (1997). The Philosophy of Money. Routledge \& Kegan Paul, London, (originally published in 1900).

[75] Smith, R. M and Miao, C. Y. (1994). Assessing unidimensionality for Rasch measurement. In M. Wilson (Ed.): Objective Measurement: Theory into Practice. Volume 2. Greenwich: Ablex.

[76] Snedecor, George W. and Cochran, William G. (1989), Statistical Methods, Eighth Edition, Iowa State University Press.

[77] Srivastava, A., Locke, E. A., \& Bartol, K. M. (2001). Money and subjective well-being: It's not the money, it's the motives. Journal of Personality and Social Psychology, 80(6), 959-971.

[78] Srivastava, A., Locke, E. A., \& Bartol, K. M. (2001). Money and subjective well-being: It's not the money, it's the motives. Journal of Personality and Social Psychology, 80(6), 959-971.

[79] Sun Y, Fang Y, Lim KH, Straub D. User satisfaction with information technology services: A social capi- tal perspective. Information Systems Research. 2012; 23(4):1195-211.

[80] Tabor, A. S. (2010). A framework for voluntary migration: Understanding modern British migration to New Zealand. Masters Thesis, Victoria University of Wellington, Wellington, New Zealand.
[81] Tabor, A. S., \& Milfont, T. L. (2011). Migration change model: Exploring the process of migration on a psychological level. International Journal of Intercultural Relations, 35 (6), 818-832. doi: 10.1016/j.ijintrel.2010.11.013

[82] Tang, T. L. P. (1992). The meaning of money revisited. Journal of Organizational Behavior, 13, 197-202.

[83] Tang, T. L. P., Sutarso, T., Akande, A., Allen, M. W., Alzubaidi, A. S., Ansari, M. A., ... Vlerick, P. (2006). The love of money and pay level satisfaction: Measurement and functional equivalence in 29 geopolitical entities around the world. Management and Organization Review, 2(3), 423-452.

[84] Tang, T. L. P., Sutarso, T., Ansari, M. A., Lim, V. K. G., Teo, T. S. H., Arias-Galicai, F., Manganelli, A. M. (2011). The love of money is the root of all evil: Pay satisfaction and CPI as moderators. In Leslie A. Toombs (Ed.), Best paper proceedings of the 2011 Annual Meeting of the Academy of Management.

[85] Tang, T. L. P., Sutarso, T., Davis, G. M. T., Dolinski, D., Ibrahim, A. H. S., \& Wagner, S. L. (2008). To help or not to help? The Good Samaritan Effect and the love of money on helping behavior. Journal of Business Ethics, 82(4), 865-887.

[86] Tang, Thomas Li-Ping et al.(2015). Monetary Intelligence and Behavioral Economics across 32 Cultures: Good Apples Enjoy Good Quality of Life in Good Barrels. Journal of Business Ethics. DOI: 10.1007/s10551-015-2980-y

[87] Tang, Thomas Li-Ping. 1998. The Meaning of Money Revisited: The Development of the Money Ethic Scale. Paper presented at the Annual Meeting of the Southwestern Psychological Association (34th, Tulsa, OK, April 21-23, 1988).

[88] Tellegen,A., \& Waller, N. G. (2008). Exploring personality through test construction: Development of the multidimensional personality questionnaire. In G. J. Boyle, G. Matthews \& D. H. Saklofske (Eds.), The sage handbook of personality theory and assessment (Vol. 2 Personality measurement and testing). Thousand Oaks, CA: Sage.

[89] Tra Mi (2015). Poverty is still high, land in the hands of the state in rural Vietnam. [Vietnamese version] https://www.voatiengviet.com/a/ngheo-doi- 
van-cao-dat-dai-roi-vao-tay-nha-nuoc-tainong-thon-vietnam/2934583.html

[90] Tran Le Huu Nghia. Motivations for Studying Abroad and Immigration Intentions: The Case of Vietnamese Students. Journal of International Students, Volume 9, Issue 3 (2019), pp. 758-776. ISSN: 2162-3104 (Print), 2166-3750 (Online) doi: 10.32674/jis.v0i0.731ojed.org/jis

[91] Tran Van Thien, Nguyen Sinh Cong (2011). Solutions to prevent escaping export labor. http://molisa.gov.vn/Pages/tintuc/chitiet.aspx ?tintucID $=20918$

[92] Truong, T. and Angeles, B. (2005). Searching for Best ractices to Counter Human Trafficking in Africa: A focus on women and children. Report commissionedby United Nations Educational, Scientific and CulturalOrganization (UNESCO)

[93] Tucker, L. R., \& Lewis, C. (1973). A reliability coefficient for maximum likelihood factor analysis. Psychometrika, 38 , $1-10$. https://doi.org/10.1007/BF02291170

[94] U.S. Embassy in Vietnam. (2019). 2019 report of Human trafficking situation. [Vietnamese version]. https://vn.usembassy.gov/vi/2018tipreport/

[95] Ullman, J. B. (2006). Structural equation modeling: Reviewing the basics and moving forward. Journal of Personality Assessment, $87(1)$, $35-$ 50.https://doi.org/10.1207/s15327752jpa870 103

[96] Wang, Z., De Graaff, T., \& Nijkamp, P. (2016). Cultural diversity and cultural distance as choice determinants of migration destination. Spatial Economic Analysis, 11(2), 176-200.

[97] Widaman. F., \& Reise, S. P. (1997). Exploring the measurement invariance of psychological instruments: Applications in the substance use domain. In K. J. Bryant, M. Windle, \& S. G.West (Eds.), The science of prevention: Methodological advances from alcohol and substance abuse research (pp. 281-324). Washington, DC: American Psychological Association. https://doi.org/10.1037/10222009

[98] Wong, H. M. (2008). Religiousness, love of money, and ethical attitudes of Malaysian evangelical Christians in business. Journal of Business Ethics, 81(1), 169-191.

[99] Wrosch, C., Heckhausen, J., \& Lachman, M. E. (2000). Primary and secondary control strategies for man-aging health and financial stress across adulthood. Psychology and Aging, 15(3), 387-399.

[100] Yamauchi, K.T. and Templer, D.I. (1982), "The development of a money attitude scale". Journal of Personality Assessment, Vol. 46, May, pp. 522-8.

[101] Zhang, L. Q. (2009). An exchange theory of money and self-esteem in decision making. Review of General Psychology, 13(1), 66-76.

[102] Zhang, L. Q., \& Baumeister, R. F. (2006). Your money or your self-esteem: Threatened egotism promotes costly entrapment in losing endeavors. Personality and Social Psychology Bulletin, 32(7), 881-893.

[103] Zhou, X. Y., Vohs, K. D., \& Baumeister, R. F. (2009). The symbolic power of money: Reminders of money alter social distress and physical pain. Psychological Science, 20(6).

\section{Creative Commons Attribution License 4.0 (Attribution 4.0 International, CC BY 4.0)}

This article is published under the terms of the Creative Commons Attribution License 4.0 https://creativecommons.org/licenses/by/4.0/deed.e n_US 


\section{Appendix}

Table 12. Items in the questionnaire

\begin{tabular}{|c|c|c|c|c|c|c|}
\hline \multirow[t]{2}{*}{ Code } & \multirow[t]{2}{*}{ My attitude about money } & \multicolumn{5}{|c|}{$\begin{array}{l}\text { Disagree strongly =1; } \\
\text { Disagree a little }=2 ; \text { Neither } \\
\text { agree nor disagree =3 ; } \\
\text { Agree a little = } 4 \text {; Agree } \\
\text { Strongly =5 }\end{array}$} \\
\hline & & 1 & 2 & 3 & 4 & 5 \\
\hline Achievement & Achievement & & & & & \\
\hline Achievement1 & Money represents one's achievement. & & & & & \\
\hline Achievement 2 & Money in the bank is a sign of security & & & & & \\
\hline Achievement3 & Money is a symbol of success. & & & & & \\
\hline Achievement4 & Money is the most important thing (goal) in my life. & & & & & \\
\hline Achievement5 & Money gives you autonomy and freedom. & & & & & \\
\hline Achievement6 & Money, the more you have, the better. & & & & & \\
\hline Good & \multicolumn{6}{|l|}{ Good } \\
\hline Good 1 & Money is attractive. & & & & & \\
\hline Good 2 & I value money very highly. & & & & & \\
\hline Good 3 & Mongy is good. & & & & & \\
\hline Good 4 & Money is important. & & & & & \\
\hline Good 5 & Money is valuable. & & & & & \\
\hline Power & \multicolumn{6}{|l|}{ Power } \\
\hline Power 1 & Money talks. & & & & & \\
\hline Power 2 & Money becomes a symbol of status in the & & & & & \\
\hline Power 3 & modern society. & & & & & \\
\hline Power 4 & Money can buy you luxuries. & & & & & \\
\hline Power 5 & Money means power. & & & & & \\
\hline Expression & \multicolumn{6}{|l|}{ Expression } \\
\hline Expression 1 & $\begin{array}{l}\text { Money makes people respect you in your } \\
\text { community. }\end{array}$ & & & & & \\
\hline Expression 2 & Money can bring you many friends. & & & & & \\
\hline Expression 3 & $\begin{array}{l}\text { Money will help you to exprpss your competence } \\
\text { and ability. }\end{array}$ & & & & & \\
\hline Expression 4 & $\begin{array}{l}\text { Money can give you the opportunity to be what you } \\
\text { want to be. }\end{array}$ & & & & & \\
\hline \multicolumn{7}{|c|}{ I see Myself as Someone Who } \\
\hline Extraversion & Extraversion & & & & & \\
\hline $\begin{array}{l}\text { Extraversion } \\
1\end{array}$ & Is talkative & & & & & \\
\hline $\begin{array}{l}\text { Extraversion } \\
2\end{array}$ & Is reserved $(\mathrm{R})$ & & & & & \\
\hline $\begin{array}{l}\text { Extraversion } \\
3\end{array}$ & Is full of energy & & & & & \\
\hline $\begin{array}{l}\text { Extraversion } \\
4\end{array}$ & Generates a lot of enthusiasm & & & & & \\
\hline $\begin{array}{l}\text { Extraversion } \\
5\end{array}$ & Tends to be quiet (R) & & & & & \\
\hline
\end{tabular}




\begin{tabular}{|c|c|c|}
\hline \multirow[b]{2}{*}{$\begin{array}{l}\text { Extraversion } \\
6\end{array}$} & \multirow[b]{2}{*}{ Has an assertive personality } & $\begin{array}{l}\text { Disagree strongly }=1 ; \\
\text { Disagree a little }=2 ; \text { Neither } \\
\text { agree nor disagree =3 ; } \\
\text { Agree a little = } 4 ; \text { Agree } \\
\text { Strongly }=5\end{array}$ \\
\hline & & \\
\hline Openness & Openness & \\
\hline Openness 1 & Is original, comes up with new ideas & \\
\hline Openness 2 & Is curious about many different things & \\
\hline Openness 3 & Is ingenious, a deep thinker & \\
\hline Openness 4 & Has an active imagination & \\
\hline Openness 5 & Is inventive & \\
\hline Openness 6 & Values artistic, aesthetic experiences & \\
\hline Openness 7 & Prefers work that is routine $(\mathrm{R})$ & \\
\hline Openness 8 & Likes to reflect, play with ideas & \\
\hline Openness 9 & Has few artistic interests $(\mathrm{R})$ & \\
\hline Openness 10 & Is sophisticated in art, music, or literature & \\
\hline Worry & My worry about finances & \\
\hline Worry 1 & I feel anxious about my financial situation. & \\
\hline Worry 2 & $\begin{array}{l}\text { I have difficulty sleeping because of my financial } \\
\text { situation. }\end{array}$ & \\
\hline Worry 3 & $\begin{array}{l}\text { I have difficulty concentrating on my school/or } \\
\text { work because of my financial situation. }\end{array}$ & \\
\hline Worry 4 & I am irritable because of my financial situation. & \\
\hline Worry 5 & $\begin{array}{l}\text { I have difficulty controlling worrying about my } \\
\text { financial situation. }\end{array}$ & \\
\hline Worry 6 & $\begin{array}{l}\text { My muscles feel tense because of worries about my } \\
\text { financial situation. }\end{array}$ & \\
\hline Worry 7 & $\begin{array}{l}\text { I feel fatigued because I worry about my financial } \\
\text { situation. }\end{array}$ & \\
\hline Intent & Intention to become illegal workers & \\
\hline Attitude1 & I have considered illegal labor & \\
\hline Attitude2 & I am very interested in getting illegal work abroad & \\
\hline Attitude3 & I expected to going abroad illegally & \\
\hline Attitude4 & $\begin{array}{l}\text { Illegal immigration is very good to earn more } \\
\text { money }\end{array}$ & \\
\hline Attitude5 & I will go abroad if someone helps & \\
\hline Attitude6 & $\begin{array}{l}\text { My family agree whith my intention of illegal } \\
\text { immigration }\end{array}$ & \\
\hline
\end{tabular}

$$
\text { (“ } R \text { " denotes reverse-scored items) }
$$

